\title{
ケノデオキシコール酸カプセル剤の品質比較試験*1
}

\author{
従二和彦, 猪爪信夫, 岩奥玲子, 中野真汎 \\ 能本大学医学部附属病院薬剤部*2
}

\section{Comparative Evaluation of Chenodeoxycholic Acid Capsules*1}

\author{
KAZUHIKo JUNI, NoBUo INOTSUME, REIKo IWAOKU, and \\ MASAHIRO NAKANO
}

Department of Pharmacy, Kumamoto University Hospital*2

(Received July 25, 1983)

Three brands of chenodeoxycholic acid capsules of the companies A, B, and C were compared. One of the three brands had very small weight deviation. Differential scanning colorimetry and scanning electron microscopy indicated that 2 brands contained crystalline drug and 1 brand contained amorphous drug. Gas-liquid chromatographic analysis of the extracts from bulk drugs and capsule formulations revealed that the 2 crystalline bulk drugs and the capsule formulations of the 2 crystalline drugs contained definite amount of ethyl acetate as residual solvent. The amount of the solvent in formulations might be reduced by purification of the bulk drug. Thinlayer chromatographic analysis of the extracts from the capsules indicated that small amount of materials other than chenodeoxycholic acid may be present in the formulations.

Keywords—chenodeoxycholic acid; weight deviation; differential scanning colorimetry; scanning electron microscopy; crystalline; amorphous; residual solvent; thin-layer chromatography; gas-liquid chromatography

\section{は じめに}

熊本大学医学部附属病院薬剂部においては, 新規購入 申請書提出時および既採用医薬品の調整時に, 医薬品に ついて製剤学的な比較試験などす含めて位置づけと評価 を行い, 医薬品の採用, 調整について審議する薬事委員 会へ資料を提出している. 今回 3 社から同時発売され， 新規購入申請されたコレステロール胆石溶解剂のケノデ オキシュール酸カプセル剤の品質比較試験を行ったので その結果を報告する。

\section{实 験 方 法}

\section{1. 測定试料}

A，B，C 3 社から提供を受けたケノデオキシコール酸 原末撤よ゙ケノデオキシコール酸 $100 \mathrm{mg}$ 含有のカプセ

*1 本報の要旨は日本薬学会第103年会病院薬学部会で 報告した。

*2 熊本市本荘1丁目1-1；1-1, Honjo 1-chome, Kumamoto, 860 Japan
ル阂（臨床試供品）を用いた. 各ロット番号を以下に示 †.
原末
カプセル剂
A社 : 92062203
2602
$B$ 社：記載なし
DL01
$\mathrm{C}$ 社 : KEN-W 3
WKW1

\section{2. 重是偏差試験}

「日局10」一般試験法第20項重量偏差試験法に準じて, カプセル剂総重量およびカプセル内容物重量を測定し た.

\section{3. 示美走态熱贯㖕による熱分析}

ケノデオキシコール酸として約 $5 \mathrm{mg}$ 含有する量の試 料を熱量計用のパンに取り, $5^{\circ} \mathrm{C} / \mathrm{min}$ の速度で昇温し， $\pm 2 \mathrm{mcal} / \mathrm{s}$ レンジで熱量変化を測定した.装置は理学電 機・示差走査熱量計（TG-DSC CN 8089A1）を使用 した。

\section{4. 走查形里子顆微鏡による観㲾}

3 社のケノデオキシコール酸原末について, 金コーテ ヘングを施した後に走查形電子顕微鏡にて形状を観察し 
た. 金コーティングにはイオンコーター (IB-3, エイコ ーエンジニアリング株式会社) を用いイオン電流 5 ～ 7 $\mathrm{mA}$ で 3 分間処理した. 走査形電子顕微鏡は MINISEM ${ }^{\otimes}$ MSM-102(日立一明石製作所)を用い，印加電圧 $15 \mathrm{kV}$ で観察した.

\section{5. 残留溶媒測定}

各カプセル阂内容物約 $1 \mathrm{~g}$ (A 社製剤 6 カプセル, B,

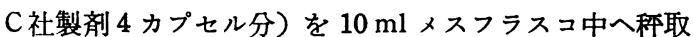
し, $8 \mathrm{ml}$ のジメチルホルムアミド (岩井化学薬品, 特 級) を加光, 超音波処理（池本理化, Sine Sonic 100型) を10分間行った後, ジメチルホルムアミドを加え $10 \mathrm{ml}$ し摫汼した。 この液をテフロンフィルター（MILEX『$\mathrm{SR}$, ポアサイズ $0.5 \mu \mathrm{m}$ ，ミリポア社）によりろ過し， ろ液中の残留溶媒を以下に述べる条件でガスクロマトグ ラフ法により分析した。なお残留溶媒としては製造過程 中, 晶出の際に用いる溶媒として報告されている酢酸エ チル, ジェチルェーテル, 石油エーテル, $\mathrm{n}$-ヘプタンが まず考えられる1 3). 今回検討した 3 社の製剤からの抽 出液を注入したところ，2 社の製剤において保持時間約 1 分と約 9 分に 2 つの゚ークが得られ，それぞれ標品と の比較で前者のピークは酢酸エチル，後者はジメチルホ ルムアミドであることが確認された，n一へプタンについ てはケノデオキシュール酸と包接化学物を形成し結晶中 に保持され得るという報告があるが,2) 標品の n-ヘプタ ンの示す保持時間 0.5 分にはピークを認めなかった．し たがって残留溶媒として検出された酢酸エチルについて 定量を行った.

カラム : $3 \mathrm{~mm} \phi \times 2 \mathrm{~m}$ ガラスカラム

充てん斉 : 15\% PEG 1500 on Chromosorb WAWDMCS

温 度: カラム; $110^{\circ} \mathrm{C}$, 注入部・検出部; $180^{\circ} \mathrm{C}$

検出器 : FID

$\mathrm{N}_{2}$ 流量 : $40 \mathrm{ml} / \mathrm{min}$

装 置：日立ガスクロマトグラフ063 型, レコーダー ; 島津 GC プロセッサー RPR-GI 型 なお定量は積分ピーク面積による絶対検量線法によっ た。

\section{6. 薄酋クロマトグラフィー}

残留溶媒測定に使用したジメチルホルムアミド抽出液 約 $5 \mu \mathrm{l}$ をシリカゲルプレート (Kieselgel $60 \mathrm{~F}_{254}$, 薄層 $0.25 \mathrm{~mm}$, メルク社）上にスポットし, 酢酸エチルーシ クロヘキサンー酢酸 (50:13:3) を溶媒として展開し た。発色にはリンモリブデン酸を使用した。

\section{結果および考察}

\section{1. 重母偏差試験}

各社カプセル阂20個ずつについて測定した結果を表 1 に示す．いずれも局方規定に適合していた．特に A 社の カプセル剤については重量偏差の非常に小さい製剤であ ることが認められた。

\section{2. 熱分析}

3 社の原末および製剤について示差走査熱量計により 得られた熱分析結果を図 1 に示した。この結果から A 社 の原末，製剤ともに $250^{\circ} \mathrm{C}$ までの範囲でピークが得ら れず結晶を有しないものと考えられた，B社，C社の原 末においては $110^{\circ} \mathrm{C}$ 付近に融点と思われる吸熱ピークが 観察されたことから結晶を有することが認められた。ま た B 社の製剤では約 $104^{\circ} \mathrm{C}, \mathrm{C}$ 社の製剤では約 $107^{\circ} \mathrm{C} に$ 吸熱ピークが観察され，原末に比べいくぶん低い温度に 融点を示したものと考えられる．なお約 $140^{\circ} \mathrm{C}$ (図中Ｉ） および約 $190^{\circ} \mathrm{C}$ (図中II) に認められたピークは製剤添 加物によるものと考えられる．またC社の製剤について は約 $76^{\circ} \mathrm{C}$ にす小なピークが検出されたが同定は行っ ていない。

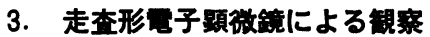

図 2 に 3 社のケノデオキシコール酸原末の走查形電子 顕微鏡写真を示した．A社の原末では結晶は見られず比 較的径の大きな粒子であることが認められた．B社の原 末は微細な粉末で小さな結晶の集合であり，C社の原末 はB社のものに比べ大きな結晶であることが認められ た. 熱分析の結果と走査形電子顕微鏡による観察の結果 から $\mathrm{A}$ 社のケノデオキシコール酸は無晶形のものであ り， $\mathrm{B}$ 社， $\mathrm{C}$ 社のものは結晶形であることが確認され た。

表 1. 重量偏差 $(n=20)$ の比較

\begin{tabular}{|c|c|c|c|c|}
\hline & \multicolumn{2}{|c|}{ カプセル玮 } & \multicolumn{2}{|c|}{ カプセル内容物 } \\
\hline & 平均 $\mathrm{l}(\mathrm{mg})$ & 变㛉数 (\%) & 平均目 $(\mathrm{m} \mathrm{g})$ & 変功係数 (\%) \\
\hline$\overline{A \text { 社 }}$ & 220.6 & 0.71 & 170.4 & 0.74 \\
\hline B社 & 302.8 & 1.51 & 251.5 & 1.91 \\
\hline C社 & 304.9 & 2.04 & 253.7 & 2.28 \\
\hline
\end{tabular}




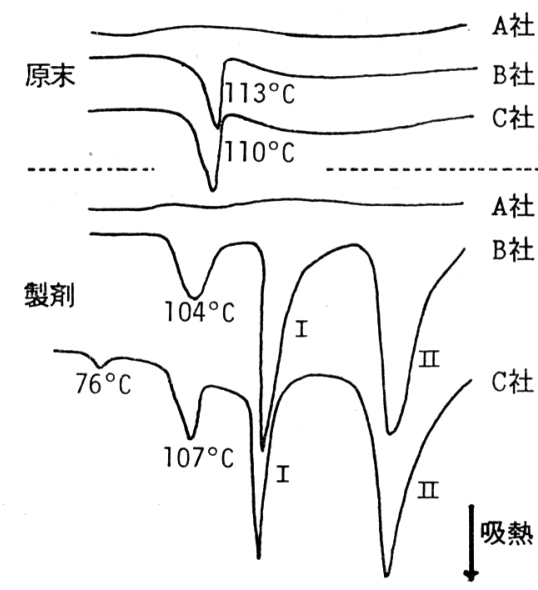

図 1.ケノデオキシュール酸原末および慗 剤の示差走查熱量計による測定結果

本実験では製剤からの溶出試験は行っていないが，ケ ノデオキシコール酸の人工腸液中に打ける溶解速度は結 晶形の違いにより差が見られなかったという報告があ る.4) ただし非常に大さな結晶（20×100 $\mu \mathrm{m}$ 程度）で は溶解速度の低下が涩められ，これを粉砕することによ り溶解速度は增大したと報告されている。四2 2 亿見られ るよらに今回検討した 3 社の原末のらち，C社のものは 比較的大きな結晶ではあるが，溶解速度にどの程度影響 するかは検討の余地があると思われる。

\section{4. 残留溶媒測定}

表 2 に残留溶媒としての酢酸エチル量を測定した結果 を示した。A社の原末，製剤共に検出されなかった， B 社， C 社の製剤に拈いては同程度の量の酶酸エチル残留 が認められた。 B社， C 社の原末については各 1 例では あるが大きな差が見られた。製剤中の残留溶媒がケノデ オキシコール酸のみに起因し，これら原末を用いて製剤

表 2. 残留溶媒（酢酸エチル）量の比較

\begin{tabular}{c|c|c}
\hline \hline \multirow{2}{*}{} & \multicolumn{2}{|c}{ 酢酸 エチル残留量 } \\
\cline { 2 - 3 } & $\begin{array}{c}\text { 製剂 } \\
\mathrm{mg} / \mathrm{g} \text { 製剤 })\end{array}$ & $\begin{array}{c}\text { 原末 } \\
(\mathrm{mg} / \mathrm{g} \text { 原末 })\end{array}$ \\
\hline $\mathrm{A}$ 社 & $\begin{array}{c}\text { 検出せず } \\
(\mathrm{n}=2)\end{array}$ & $\begin{array}{c}\text { 検出せず } \\
(\mathrm{n}=1)\end{array}$ \\
\hline B 社 & $\begin{array}{c}2.35 * \\
(\mathrm{n}=2)\end{array}$ & $\left.\begin{array}{c}0.41 \\
\mathrm{n}=1\end{array}\right)$ \\
\hline $\mathrm{C}$ 社 & $\left.\begin{array}{c}2.32 \\
\mathrm{n}=2\end{array}\right)$ & $\left.\begin{array}{c}4.13 \\
\mathrm{n}=1\end{array}\right)$ \\
\hline
\end{tabular}

*平均值

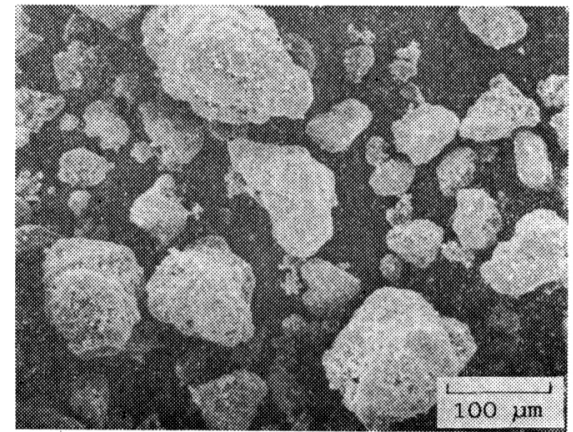

$\mathrm{A}$ 社原末 $(\times 200)$

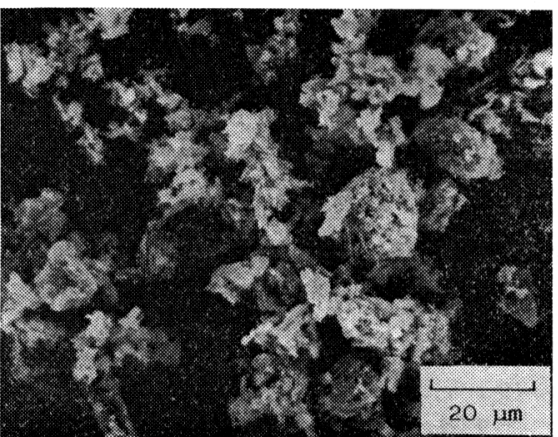

$\mathrm{B}$ 社原末 $(\times 1000)$

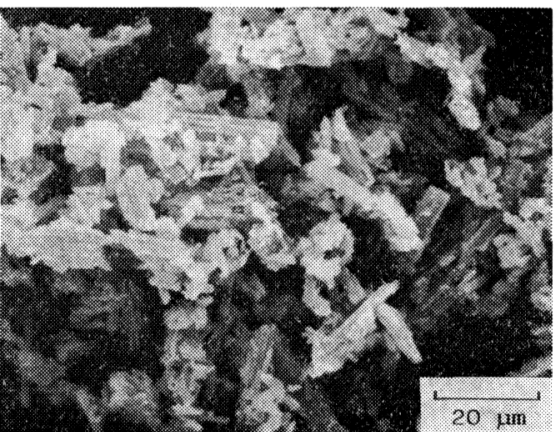

$\mathrm{C}$ 社原末 $(\times 1000)$

図 2.ケノデオキシュール酸原末の走査形電子顕微 鏡写真

を調製するとして単純に比例計算すると，製郕 $1 \mathrm{~g}$ あた り $\mathrm{B}$ 社のもので $0.16 \mathrm{mg}, \mathrm{C}$ 社のもので $1.63 \mathrm{mg}$ 程度 の残留溶媒量となるが，実際の製剂中の残留溶媒量はよ り大きな值を示している。したがって原末段階での精製 により残留溶媒量の低減は可能であると考觉られる。

\section{5. 薄層クロマトグラフィー}

図 3 に示すよらにヶノデオキシュール酸によると推定 されるメインスポットが Rf 0.59 に得られた. このス ポット以外に 3 社の製剤共に Rf 0.63 亿弱い発色ながら スポットを認めた。ささらにA社のものではRf 0.77 に, C社のものでRf 0.35 にわずかな発色を認めた。 これら 各スポットを示す物質の同定, 定量は行っていないが, 


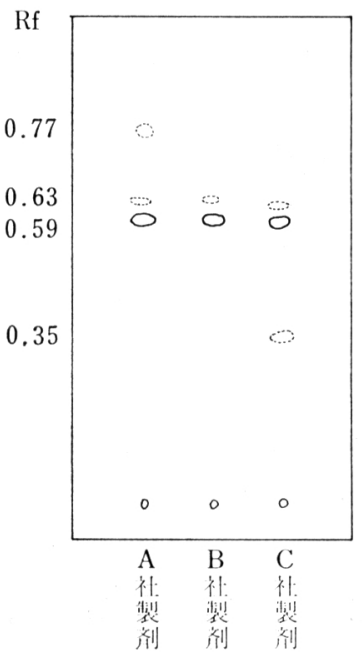

図3.ケノデオキシュール酸カプセル剤 抽出物の薄層クロマトグラム

ケノデオキシコール酸以外の胆汁酸あるいはケノデオキ シコール酸の重合物などによるものと推察される。
以上ケノデオキシコール酸カプセル剤の品質比較試験 の結果を述べた，検討を行った 3 社の製剤のらち 1 社の ものは無晶形, 他の 2 社のものは結晶形のケノデオキシ コール酸を含有することが確認された、結晶形を用いた 2 社の製剂中には約 $0.2 \%$ の酢酸エチルが残留溶媒とし て検出された。また薄層クロマトグラフィーの結果から 製剂中にはケノデオキシコール酸以外に微量の物質の存 在が示唆された。

謝辞 本検討にあたり各サンプルを提供いただいたエ 一ザイ株式会社, 東京田辺製薬株式会社, 山之内製薬株 式会社に潹く感謝いたします。

\section{文献}

1) The Merck Index, 9th Edition, p.258 (1976).

2) E.H. Mosbach, G. Nicolau, and R.W.Nichols: Lancet, July 13, p.111 (1974).

3) P. van Straelen, H. A.P. de Jongh, and F.H. Jansen : Lancet, December 21, p.1518 (1974).

4) G.P. van Berge-Henegouwen, A.F. Hofman, and T.S. Gaginella : Gastroenterology, 73, 291 (1977).

\section{等張で200Cal/L補給できる維持液}

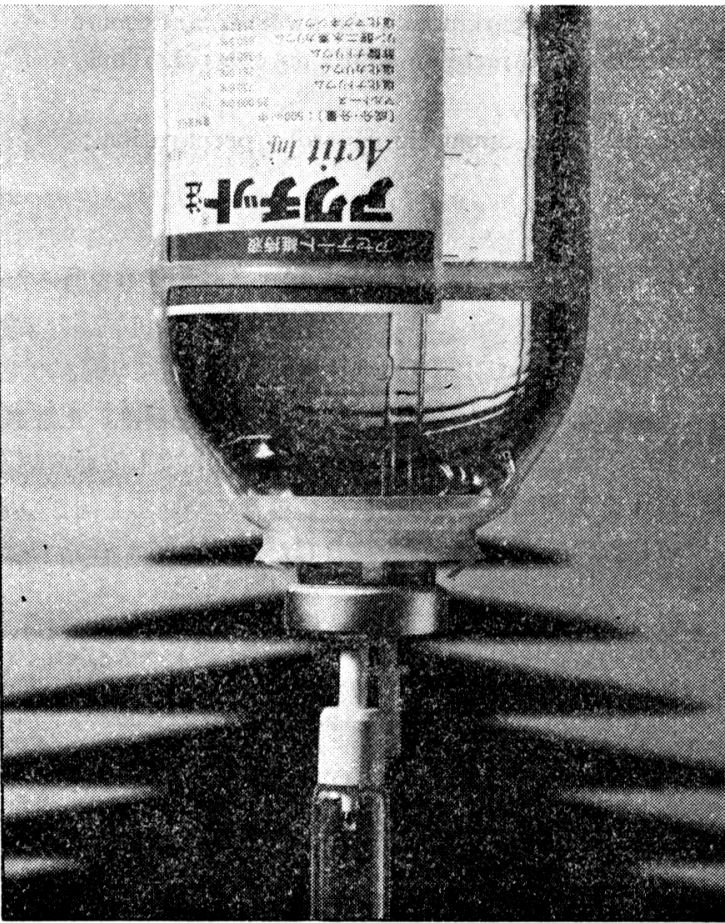

アセテート維持液

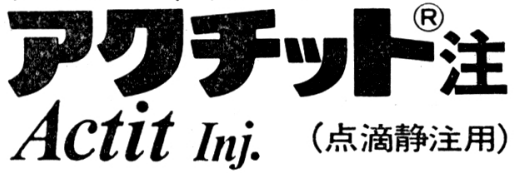

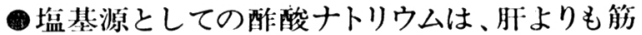
肉およびその他の末梢組織において代謝され、 かつ、乳酸ナトリウムとは異る代謝経路により速 やかに代謝され塩基源として有効に作用します。 ○マルトースはインスリン依存性が少く、非経口 投与の場合、糖尿病及び糖尿病状態時(外科的 糖尿病)にもよく利用され、従来の $5 \mathrm{~W} / \mathrm{V} \%$ 糖加 維持液と同様に 1 l当り $200 \mathrm{Cal}$ 熱量補給が可 能です。

*用法・用量、使用上の注意等は製品添付文書をご参照下さい。

健保適用 